\title{
Starch Accumulation and Granule Size Distribution of Cassava cv. Rayong 9 Grown under Irrigated and Rainfed Conditions Using Different Growing Seasons
}

\author{
Anon Janket ${ }^{1}$, Nimitr Vorasoot ${ }^{1}$, Banyong Toomsan ${ }^{1}$, Wanwipa Kaewpradit ${ }^{1}$, Sanun Jogloy ${ }^{1,2}$, \\ Piyada Theerakulpisut ${ }^{3}$, C. Corley Holbrook ${ }^{4}\left(\mathbb{D}\right.$, Craig K. Kvien ${ }^{5}$ and Poramate Banterng ${ }^{1, *(D)}$ \\ 1 Department of Agronomy, Faculty of Agriculture, Khon Kaen University, Khon Kaen 40002, Thailand; \\ anon.agron@gmail.com (A.J.); nimitr1945@gmail.com (N.V.); banyang@kku.ac.th (B.T.); \\ wanwka@gmail.com (W.K.); sjogloy@gmail.com (S.J.) \\ 2 Peanut and Jerusalem Artichoke Improvement for Functional Food Research Group, Khon Kaen University, \\ Khon Kaen 40002, Thailand \\ 3 Department of Biology, Faculty of Science, Khon Kaen University, Khon Kaen 40002, Thailand; \\ piythe@kku.ac.th \\ 4 Crop Genetics and Breeding Research Unit, USDA-ARS, Tifton, GA 31793, USA; \\ corley.holbrook@ars.usda.gov \\ 5 Department of Crop \& Soil Sciences, University of Georgia, Tifton, GA 31793, USA; ckvien@uga.edu \\ * Correspondence: bporam@kku.ac.th; Tel.: +66-43-342-949
}

Received: 8 February 2020; Accepted: 17 March 2020; Published: 19 March 2020

\begin{abstract}
Although cassava can be planted throughout the year, its starch qualities may vary based on the date of planting. Seasonal variation on starch content, starch yield, starch granule size and amylose content of cassava cv. Rayong 9 grown under irrigated and rainfed conditions were studied for four planting dates in Thailand. A randomized complete block design with four replications was used in each planting. Planting dates consisted of hot-dry (20-Apr), early-rainy (30-Jun), late-rainy (5-Oct) and cool seasons (15-Dec). At final harvest, planting date accounted for the largest variations for starch yield $(60.8 \%)$, starch granule size $(38.2 \%)$, amylose content $(50.5 \%)$ and ratio of amylose to amylopectin $(53.7 \%)$, whereas starch content was affected more by water regime (52.1\%). Supplemental irrigation did not significantly increase starch yield and other parameters for most planting dates, except for starch yield of the crop planted in the hot-dry season. This indicated that irrigation at the late-growth stages (during Sep to Mar) for the crop planted in the hot-dry season helped to increase starch yield; however, irrigation was unnecessary for other planting dates once cassava was established. The crops planted in the late-rainy and cool seasons had a greater starch content and starch yield than other planting dates for both irrigated and rainfed crops, whereas the crop planted in the hot-dry season had high starch yield for the irrigated crops only. In this study, the crops planted in the early-rainy season showed the worst performances for starch content and starch yield for both irrigated and rainfed crops. The data provided information on the responses of starch yield and its characteristics under irrigated and rainfed conditions at different planting dates, which can be useful for designing cultural practices with respect to water management and planting period in order to obtain optimum starch yield and qualities.
\end{abstract}

Keywords: drought stress; environmental impact; Manihot esculenta; seasonal variation; starch content

\section{Introduction}

Cassava (Manihot esculenta Crantz) is an important industrial crop in many countries, and it is considered as a staple food for the rural areas of the tropics because of its inherent adaptation to 
marginal environments, making it an ideal food security and subsistence crop. It also can be used for animal feed and biofuels [1,2]. Cassava is produced in tropical and sub-tropical regions [3]. In Thailand, cassava is considered as a major crop, and Thailand is an important exporter for cassava [4]. Although cassava is a hardy plant under unfavorable environments, drought stress is still an important cause of yield reduction compared to yield potential under favorable environments [5-7].

Cassava has a long crop cycle in which the growing period of nearly 12 months covers all seasons of the year. Cassava genotypes have been shown to respond differently to weather conditions during the growth periods of different planting seasons [8-10]. The weather cycles associated with the crop cycles of cassava planted at different planting dates of the year, especially for drought events occurring at different growth stages, might cause different performances of the crop. Thus, understanding on crop responses to drought stress is of great significance and also a fundamental part of abiotic stress-breeding schemes and sustainable agriculture [11].

Drought stress at all growth stages affected starch content, starch yield and quality of cassava; however, the ability of cassava to tolerate the drought stress depends on the timing, drought severity and duration of the event. Earlier studies have reported that cassava planted in the early-rainy season (without initial water stress) had higher starch content and root yield than cassava planted in the post-rainy season (with initial water stress) by $16.46 \%$ to $24.46 \%$ and $11.81 \%$ to $35.64 \%$, respectively [12]. In addition, cassava planted in the rainy season had larger starch granules than the crop planted in the dry season [13]. Drought stress reduced granule size, and the early season stress had a greater detrimental effect than terminal water stress $[12,14]$. However, seasonal variation and drought stress had minor effects on amylose and amylopectin in the storage root of cassava [14]. Janket et al. [8] have demonstrated that, under full irrigation, planting cassava in late-rainy seasons (October and December) with higher temperatures and solar radiation during summer and rainy seasons (at the time of the stem and leaf development stage until high translocation of carbohydrate to storage roots) gave a greater starch content and starch yield compared to planting cassava in the early-rainy seasons (April and June).

If water resources are available, irrigation is an interesting option for increasing starch yield and quality of cassava. Unfortunately, the detailed description of starch accumulation and related starch traits of rainfed and well-watered cassava grown in different planting dates has not yet been clearly investigated. The aim of this study was to investigate the effects of seasonal variation on starch content, starch yield, granule size distribution, amylose and amylopectin contents of a commercially important cultivar of cassava (Rayong 9) in different planting dates under irrigation and rainfed conditions. A better understanding of the behavior of starch traits of cassava planted in different dates in responses to well-watered and rainfed conditions may provide useful information for designing effective guidelines for improving the water management and planting time of cassava growing in different seasons in order to obtain the highest starch yield in tropical environments.

\section{Materials and Methods}

\subsection{Plant Materials, Experimental Design and Crop Management}

Rayong 9 cassava was used in study. It is a nonbranching type released by the Department of Agriculture, Thailand and widely grown in Thailand. This variety was selected because of its high starch content, wide adaptability to different environmental conditions and high yield potential [15]. A hardpan was broken by a chisel tractor at 30-60 $\mathrm{cm}$ below the soil surface, and the soil was then prepared conventionally. The stems of cassava at the age of 9 months were cut into the stakes of $20 \mathrm{~cm}$ in length, and the stem cuttings were soaked with thiamethoxam $25 \%$ water-dispersible granules (WG) (Syngenta Crop Protection Limited, Bangkok, Thailand) at the rate of $4 \mathrm{~g}$ per $20 \mathrm{~L}$ of water for $30 \mathrm{~min}$ to control mealy bugs [16].

The stem cuttings were germinated in warm conditions and then planted vertically on the top of ridges at $1 \times 1$ distance in the $5 \times 7$ plots. In order to maintain the uniformity for plant population 
during germination, the dried plants were replaced with the germinated stem cuttings within the first month. The experiment was carried out at Khon Kaen, Thailand $\left(16^{\circ} 28^{\prime} \mathrm{N}\right.$ and $102^{\circ} 48^{\prime} \mathrm{E}, 195$ masl) during 2015-2016 by using a randomized complete block design (RCBD) with four replications under irrigated and rainfed conditions. During the first 30 days after planting, both irrigated and rainfed plots were irrigated by using a mini-sprinkler system, which was installed before planting. The soil moisture was maintained at a level close to field capacity in order to enhance good crop establishment. The soil moisture content was monitored by a tensiometer, which was installed in the first replication at 20 and 40-cm soil depth. After 30 days after planting, irrigation was applied only to the irrigated plots, whereas irrigation for the rainfed treatment was stopped from 30 days after planting until harvest. In the irrigated plots, irrigation was applied when the soil water tension at the 20-cm depth was lower than $-30 \mathrm{kPa}$, and water was supplied until the soil suction increased to $0 \mathrm{kPa}$.

Weeds were controlled by application of alachlor (2-cholro-2, 6'-diethyl-N-(methoxymethyl) acetanilide $48 \%, \mathrm{w} \mathrm{v}^{-1}$, emulsifiable concentrate) (Kemfac Limited, Samutprakan, Thailand) at the rate of $3 \mathrm{~L} \mathrm{ha}^{-1}$ before planting and manual weeding was carried out during the remainder of the season. Fertilizer was applied after weed control based on soil chemical properties and recommended by the Department of Agriculture [16] and Howeler [17]. Mealy bugs (Centrococcus insolitus) were controlled by an application of thiamethoxam (3-(2-chloro-thiazol-5-ylmethyl)-5-methyl-(1,3,5)-oxadiazinan-4-ylidene-N-nitroamine $25 \% \mathrm{WG}$ ) at the rate of $4 \mathrm{~g}$ per $20 \mathrm{~L}^{-1}$ water, and red mites (Eutetranychus oirentalis) were controlled by application of amitraz (N-methylbis (2,4-xylyiminomethyl) ameine $20 \% \mathrm{w} / \mathrm{v}$ EC) (Sotus International, Nonthaburi, Thailand) at the rate of $20 \mathrm{~mL}$ per $20 \mathrm{~L}^{-1}$ water.

\subsection{Data Collection}

\subsubsection{Meteorological Condition and Soil Properties}

The weather data, including minimum, maximum and mean temperatures $\left({ }^{\circ} \mathrm{C}\right)$; rainfall $(\mathrm{mm})$; photoperiod (h); ambient relative humidity (\%) and solar radiation $\left(\mathrm{MJ} \mathrm{m}^{-2} \mathrm{day}^{-1}\right)$, at the study site were recorded daily from planting until harvest by a meteorological station model Watch Dog 2700, which was located in the experimental site (Watchdog, PCE Germany, Meschede, Germany). Soil samples were randomly taken before planting at depths of 0-30 and 30-60 cm. The soil samples were analyzed for soil physicochemical properties, including soil $\mathrm{pH}$, organic matter, total nitrogen, available phosphorus, exchangeable potassium, calcium, magnesium, sulfur, electrical conductivity (EC) and cation exchange capacity (CEC).

All experiments were on a Yasothon series (Yt: fine-loamy; siliceous, isohypothermic and oxic paleustults) in Northeast Thailand (Table 1). The soil texture was loamy sand with average soil pH at $0-60 \mathrm{~cm}$ soil layers ranging from 5.67 to 7.04 . On average, at $0-60 \mathrm{~cm}$ soil layers, the soil chemical properties before fertilization of four planting dates had total nitrogen ranging from $0.01 \%$ to $0.03 \%$, exchangeable potassium ranging from 12.8 to $54.6 \mathrm{mg} \mathrm{kg}^{-1}$, total magnesium ranging from 30.8 to $50.4 \mathrm{mg} \mathrm{kg}^{-1}$, organic matter ranging from $0.33 \%$ to $0.53 \%$ and cation exchange capacity ranging from 1.8 to $5.3 \mathrm{cmol} \mathrm{kg}^{-1}$. According to cassava nutrient requirements proposed by Howeler [17], these chemical properties were classified as insufficient concentration for optimal crop growth. However, exchangeable calcium, total sulfur and electrical conductivity for all planting dates were medium, ranging from 200 to $387 \mathrm{mg} \mathrm{kg}^{-1}, 3.0$ to $53.5 \mathrm{mg} \mathrm{kg}^{-1}$ and 0.02 to $0.05 \mathrm{dS} \mathrm{m}^{-1}$, respectively. The soil in this experiment field had sufficient available phosphorus for optimal crop growth, with the values ranging from 17.2 to $62.9 \mathrm{mg} \mathrm{kg}^{-1}$ [17]. 
Table 1. Soil physicochemical properties at preplanting in the experimental fields at the depths $0-30 \mathrm{~cm}$ and $30-60 \mathrm{~cm}$.

\begin{tabular}{|c|c|c|c|c|c|c|c|c|}
\hline \multirow{2}{*}{ Soil Physicochemical Property } & \multicolumn{2}{|c|}{ 20-Apr } & \multicolumn{2}{|c|}{ 30-Jun } & \multicolumn{2}{|c|}{ 5-Oct } & \multicolumn{2}{|c|}{ 15-Dec } \\
\hline & $0-30 \mathrm{~cm}$ & $30-60 \mathrm{~cm}$ & $0-30 \mathrm{~cm}$ & $30-60 \mathrm{~cm}$ & $0-30 \mathrm{~cm}$ & $30-60 \mathrm{~cm}$ & $0-30 \mathrm{~cm}$ & $30-60 \mathrm{~cm}$ \\
\hline \multicolumn{9}{|l|}{ Physical property } \\
\hline Sand (\%) & 83.9 & 84.4 & 85.4 & 78.5 & 85.5 & 73.0 & 85.8 & 78.3 \\
\hline Silt (\%) & 10.0 & 9.5 & 7.6 & 7.5 & 8.5 & 10.0 & 10.1 & 12.3 \\
\hline Clay $(\%)$ & 6.1 & 6.1 & 7.0 & 14.0 & 6.0 & 17.0 & 4.1 & 9.5 \\
\hline \multicolumn{9}{|l|}{ Chemical properties at preplanting } \\
\hline Total N (\%) & 0.02 & 0.02 & 0.03 & 0.02 & 0.02 & 0.01 & 0.02 & 0.01 \\
\hline Available P $\left(\mathrm{mg} \mathrm{kg}^{-1}\right)$ & 61.2 & 56.5 & 24.5 & 17.2 & 62.9 & 22.7 & 25.7 & 17.4 \\
\hline Exchangeable $\mathrm{K}\left(\mathrm{mg} \mathrm{kg}^{-1}\right)$ & 54.6 & 35.6 & 34.2 & 20.2 & 49.0 & 12.8 & 41.4 & 16.6 \\
\hline Exchangeable $\mathrm{Ca}\left(\mathrm{mg} \mathrm{kg}^{-1}\right)$ & 339 & 387 & 335 & 379 & 200 & 287 & 245 & 225 \\
\hline $\mathrm{Mg}\left(\mathrm{mg} \mathrm{kg}^{-1}\right)$ & 36.3 & 34.9 & 50.4 & 46.3 & 39.7 & 40.1 & 30.8 & 38.4 \\
\hline $\mathrm{S}\left(\mathrm{mg} \mathrm{kg}^{-1}\right)$ & 53.5 & 43.2 & 47.5 & 41.1 & 5.4 & 19.3 & 3.0 & 8.3 \\
\hline Exchangeable $\mathrm{Na}\left(\mathrm{mg} \mathrm{kg}^{-1}\right)$ & 47.4 & 42.4 & 24.8 & 25.3 & 26.2 & 24.9 & 25.7 & 24.0 \\
\hline $\mathrm{pH}\left(1: 1 \mathrm{H}_{2} \mathrm{O}\right)$ & 6.6 & 6.7 & 5.8 & 6.1 & 5.6 & 5.3 & 5.6 & 5.5 \\
\hline $\mathrm{EC}\left(\mathrm{dS} \mathrm{m}^{-1}\right)$ & 0.05 & 0.04 & 0.06 & 0.03 & 0.03 & 0.03 & 0.03 & 0.02 \\
\hline OM $(\%)$ & 0.44 & 0.43 & 0.53 & 0.38 & 0.46 & 0.33 & 0.44 & 0.34 \\
\hline $\mathrm{CEC}\left(\mathrm{cmol} \mathrm{kg}^{-1}\right)$ & 3.3 & 5.3 & 1.8 & 2.8 & 2.0 & 5.3 & 3.0 & 4.8 \\
\hline
\end{tabular}

$\mathrm{N}=$ nitrogen, $\mathrm{P}=$ phosphorus, $\mathrm{K}=$ potassium, $\mathrm{Ca}=$ calcium, $\mathrm{Mg}=$ magnesium, $\mathrm{S}=$ sulfur, $\mathrm{EC}=$ electrical conductivity, $\mathrm{CEC}=$ cation exchange capacity and $\mathrm{OM}=$ organic matter.

\subsubsection{Storage Root Dry Weight and Sample Preparation for Laboratory Analyses}

Storage root dry weights were obtained from eighteen plants in each plot at final harvest (12 months after planting (MAP)). Storage roots were removed from the plant, and fresh weight was recorded immediately. At least $10 \%$ of total storage root fresh weights were sub-sampled, and these samples were then oven-dried at $80^{\circ} \mathrm{C}$ until the weight was constant to determine dry weights. The remaining fresh storage roots in each plot (approximately eight to twelve storage roots) were immediately sub-sampled, washed in tap water and then peeled for granule size distribution determination. The sub-samples for starch content and amylose and amylopectin determinations were unpeeled. The sub-samples were sliced into small chips and oven-dried at $50-55{ }^{\circ} \mathrm{C}$ for $48 \mathrm{~h}$ or until a constant weight using a tray drier (EQ-04SW, Leehwa Industry Company, Kyongbuk, Korea). The chipped samples were ground into powder by a grinder (Standard EM-11, Sharp Thai Company Limited, Bangkok, Thailand), and the powdered samples were sieved through a $200 \mu \mathrm{m}$ mesh screen for starch content and amylose and amylopectin determinations, whereas the powdered samples for granule size distribution were sieved through a $106 \mu \mathrm{m}$ mesh screen.

\subsubsection{Determination of Starch Content and Starch Yield}

Starch content was determined by the polarimetric method [8]. To determine total rotator power (P) of the solution, the ground sample of $5 \mathrm{~g}$ was transferred to a $200-\mathrm{mL}$ flask, and then $50 \mathrm{~mL}$ of hydrochloric acid (0.31 N) (RCI Labscan Limited, Bangkok, Thailand) was added. The flask was plugged and shaken for 3 min or until the sample was uniformly suspended, and then an additional $50 \mathrm{~mL}$ of hydrochloric acid was added. The flask was immersed in a boiling water bath, shaken vigorously and steadily to avoid coagulation of the sample and kept in the bath for a total of $15 \mathrm{~min}$. Then, $60 \mathrm{~mL}$ of cold water was added to obtain a temperature of $20^{\circ} \mathrm{C}$. After cooling, $20 \mathrm{~mL}$ of $4 \%$ sodium phosphotungstate (Sigma-Aldrich Company Limited, St. Louis, Mi, USA) was added, and samples were shaken for approximately $30 \mathrm{~s}$. The sample was diluted to $200 \mathrm{~mL}$ with distilled water, mixed and filtered using no.1 filter paper. The first portion $(25 \mathrm{~mL})$ of the solution was discarded, and the remaining solution was transferred into a $200 \mathrm{~mL}$ tube, and total rotary power was measured with a polarimeter (Polatronic MH8, Schmidt Haensch, Berlin, Germany).

To determine the rotary power $\left(\mathrm{P}^{\prime}\right)$ of the solution, $12.5 \mathrm{~g}$ of the ground samples were transferred to a $250-\mathrm{mL}$ flask, and $200 \mathrm{~mL}$ of distilled water was added. The flask was shaken strongly every $10 \mathrm{~min}$ for a total of $1 \mathrm{~h}$ (6 times) in order to disperse the sample. The solution was diluted to $250 \mathrm{~mL}$ with distilled water, mixed, allowed to stand and then filtered through a no.42 filter paper. A total $100 \mathrm{~mL}$ of the filtrate was transferred into a $200-\mathrm{mL}$ flask, and $4.2 \mathrm{~mL}$ of $25 \%$ hydrochloric acid then 
was added to the filtrate, and the sample was shaken strongly. The flask was then immersed in a boiling water bath for $15 \mathrm{~min}$, and the processes for rotary power determination were continued as mentioned above. Starch content (\%) was calculated as follows:

$$
\text { Starch content }(\%)=\frac{\left[2000 \times\left(\mathrm{P}-\mathrm{P}^{\prime}\right) \times 100 \times \mathrm{L}\right]}{\left[(\mathrm{a}) 20^{\circ} \mathrm{D} \times(100-\mathrm{M})\right]}
$$

where $\mathrm{P}=$ total rotator power in degrees, $\mathrm{P}^{\prime}=$ rotator power in degrees given by substances soluble in water, $\mathrm{L}=$ standard tube length $(200 \mathrm{~mm}$ is 1$),(\mathrm{a}) 20^{\circ} \mathrm{D}=$ specifies optical rotation of pure starch (cassava starch $\left.=180^{\circ}\right)$, and $\mathrm{M}=$ starch moisture $(\%)$.

Starch content was reported on a dry weight basis, and starch yield $\left(\mathrm{kg} \mathrm{ha}^{-1}\right)$ was calculated by multiplying starch content (\%) and storage root dry weight $\left(\mathrm{kg} \mathrm{ha}^{-1}\right)$.

\subsubsection{Determination of Starch Granule Size Distribution}

Granule size distribution was determined by the laser diffraction method [13]. Starch sample was prepared by suspending in de-ionized distilled water and sonicating by ultrasonic bath $(50 / 60 \mathrm{~Hz}, \mathrm{Ney}$, Sacramento, CA, USA) for $30 \mathrm{~min}$, and then the distribution of starch particle size was observed by using laser diffraction spectrometer (Mastersizer 2000, Malvern Instruments Limited, Malvern, UK).

\subsubsection{Determination of Amylose and Amylopectin}

Amylose content was analyzed using the method described by Hoover and Ratnayake [18]. In brief, sieved cassava starch $(20 \mathrm{mg})$ was mixed with $8 \mathrm{~mL}$ of $90 \%$ dimethyl sulfoxide (DSMO) (Sigma-Aldrich Company Limited, St. Louis, MI, USA), and the mixture was heated in a boiling water bath for $15 \mathrm{~min}$. Subsequently, distilled water was added to the mixture to make up the final volume to $25 \mathrm{~mL}$. A sample of one millimeter of mixture solution was then added to $40 \mathrm{~mL}$ of distilled water and stained by $5 \mathrm{~mL}$ of a solution containing $0.06345 \%$ iodine $\left(\mathrm{I}_{2}\right)$ and $0.1079 \%$ potassium iodide (KI) (Sigma-Aldrich Company Limited, St. Louis, MI, USA) and made up to the final volume of $50 \mathrm{~mL}$. The solution was stirred and allowed to stand for $15 \mathrm{~min}$ at room temperature, and then absorbance was measured at $600 \mathrm{~nm}$ using UV-VIS spectrophotometer (Genesys 10s UV-VIS spectrophotometer, Thermo Fisher Scientific, Madison, WI, USA). The amylose percentage of the sample was calculated as a percentage of the total cassava starch sample by comparing with a standard absorption curve of potato amylose (cat. No. 10130, Fluka, Buchs, Switzerland), and amylopectin percentage of the starch samples was calculated by using the following equation:

$$
\text { Amylopectin }(\%)=100 \%-\text { amylose }(\%)
$$

The ratio of amylose to amylopectin was also calculated by dividing total amylose by total amylopectin.

\subsection{Statistical Analysis}

Analysis of variance for individual planting dates were performed. Error variances for the four planting dates were tested for homogeneity by Bartlett's test, and combined analysis of variance of four seasons with variance homogeneity were analyzed by following the procedure described by Gomez and Gomez [19]. Duncan's multiple range test (DMRT) was used to compare means within planting dates, and least significant difference (LSD) was used to compare means between water regimes for each planting date. A stepwise regression analysis was used to examine the relationship between starch traits and climatic factors (total solar radiation, minimum-maximum temperatures, mean temperature, photoperiod, relative humidity, growing degree-days and total rainfall) and water supplied. All statistical procedures were done by using MSTAT-C version 1.42 software package (Michigan State University, East Lansing, MI, USA) [20]. 


\section{Results}

\subsection{Weather Conditions and Soil Water Status}

The crop planted in the hot-dry season (20-Apr) received high temperatures, high solar radiation, high ambient relative humidity and longer photoperiod for the first few MAP (Figure 1). During 2-8 MAP, the crop planted in this planting date received lower temperatures, lower solar radiation, lower ambient relative humidity and shorter photoperiod, which occurred during the period of canopy and root development to high translocation of carbohydrates from shoot to storage roots. Similar to 20-Apr, the crop planted in the early-rainy season (30-Jun) received lower solar radiation, lower air temperature, lower ambient relative humidity and shorter photoperiod during 2 to 8 MAP.

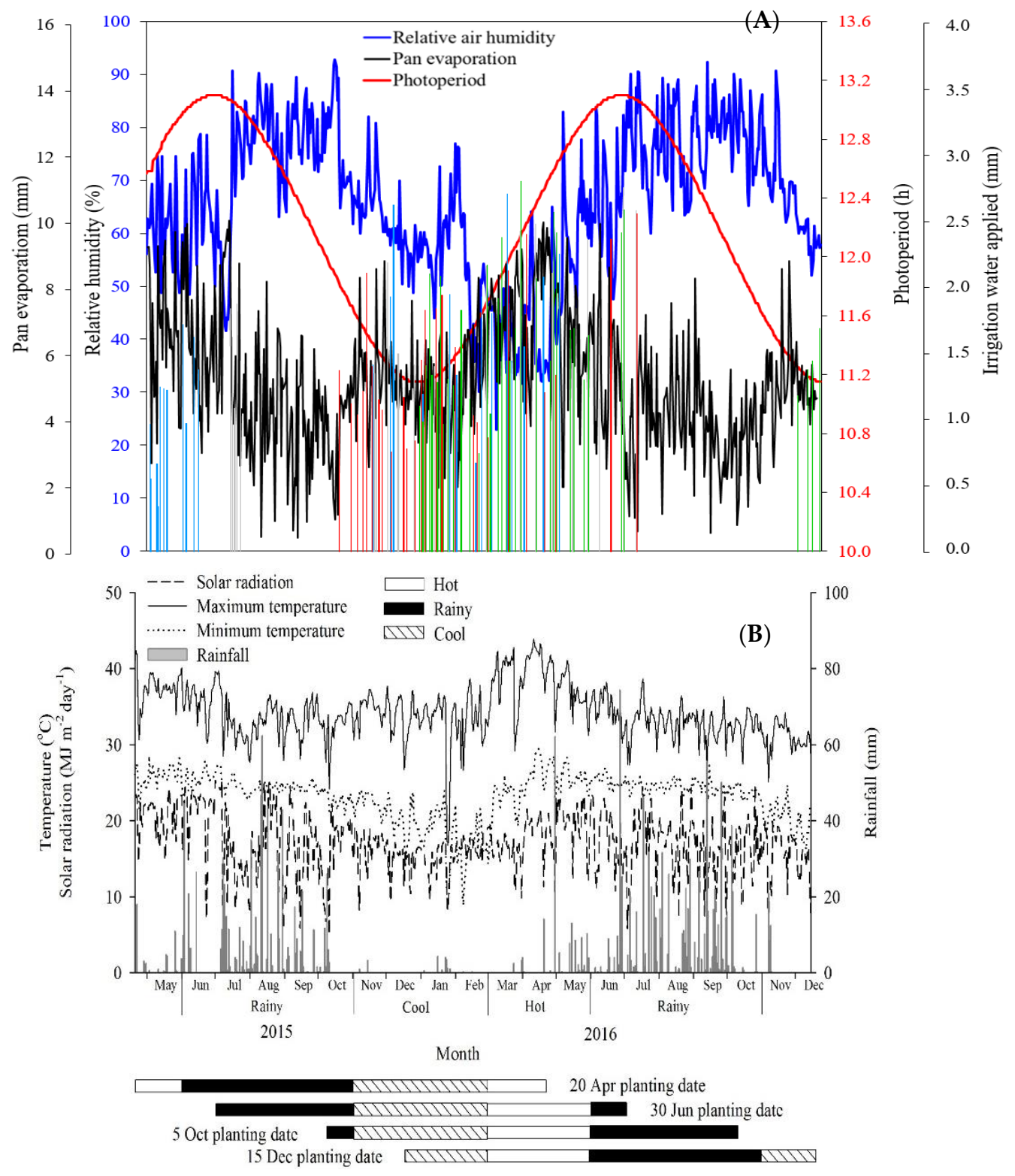

Figure 1. Pan evaporation (mm); relative air humidity (\%); photoperiod (h); irrigation events (mm) (A); maximum and minimum air temperatures $\left({ }^{\circ} \mathrm{C}\right)$; solar radiation $\left(\mathrm{MJ} \mathrm{m}^{-2} \mathrm{day}^{-1}\right)$ and rainfall $(\mathrm{mm})$ (B) during the crop growth period of cassava. The bar chart with different bar colors in Figure 1A represents the irrigation events during the crop growth period of cassava for different planting dates (blue, gray, red and green represent 20-Apr, 30-Jun, 5-Oct and 15-Dec, respectively). 
All climatic factors in the late-rainy (5-Oct) and cool season (15-Dec) were similar, and the crops received lower temperature, lower solar radiation, lower ambient relative humidity and shorter photoperiod during the early growth stages (1 to 4 MAP). Subsequently, the crops received high temperature, high solar radiation, high ambient relative humidity and longer photoperiod for the long-term during 5 to $10 \mathrm{MAP}$, which occurred during the crop period of canopy and root development to high translocation of carbohydrate from shoot to storage root. All climatic factors during the late-growth stages (10 to $12 \mathrm{MAP}$ ) in the late-rainy and cool seasons were similar to the initial plant growth stages. In this experiment, the wet season started from the middle of May and stopped in early October. Peak rainfall intensity was recorded during Jun to Aug and declined thereafter. Total rainfall recorded over the experimental period was $792.8 \mathrm{~mm}, 901.7 \mathrm{~mm}, 1039.9 \mathrm{~mm}$ and 1,119.4 $\mathrm{mm}$ for the crops planted in the hot-dry (20-Apr), early-rainy (30-Jun), late-rainy (5-Oct) and cool seasons (15-Dec), respectively (Figure 1).

The soil water potential was recorded by tensiometers indicating that the rainfed crops planted in the hot-dry (20-Apr) and early-rainy (30-Jun) seasons were subjected to low soil water potential (soil water potential fell below the critical level at $-30 \mathrm{KPa}$ ) at mid to late-growth stages (Table 2). The crop planted in the hot-dry season (20-Apr) was subjected to drought during 7-12 MAP, whereas the crop planted in the early-rainy season (30-Jun) was subjected to drought during 5-11 MAP. The crops planted in the late-rainy (5-Oct) and cool seasons (15-Dec) were subjected to low soil water potential during early to mid-growth stages. The crops planted in the late-rainy season (5-Oct) were subjected to drought during 2-6 MAP, whereas the crop planted in the cool season (5-Dec) were subjected to drought during 2-5 MAP. Moreover, the crops planted in the cool season (5-Dec) were also subjected to drought at 12 MAP. No water stress was observed during the growing season for irrigated crops for all planting dates (Table 2), because the cassava crops were partially watered during the wet season and fully watered during the dry season (Figure 1).

Table 2. The number of days the soil water potential fell below the critical level ( $-30 \mathrm{KPa})$ for cassava cv. Rayong 9 under irrigated and rainfed conditions using four planting dates.

\begin{tabular}{ccccccccc}
\hline \multirow{2}{*}{ Months after Planting } & \multicolumn{2}{c}{ 20-Apr } & \multicolumn{2}{c}{ 30-Jun } & \multicolumn{2}{c}{ 5-Oct } & \multicolumn{2}{c}{ 15-Dec } \\
\cline { 2 - 8 } & Irrigation & Rainfed & Irrigation & Rainfed & Irrigation & Rainfed & Irrigation Rainfed \\
\hline $1-3$ & 0 & 10 & 0 & 0 & 0 & 50 & 0 & 56 \\
$4-6$ & 0 & 0 & 0 & 42 & 0 & 90 & 0 & 65 \\
$7-9$ & 0 & 90 & 0 & 90 & 0 & 35 & 0 & 6 \\
$10-12$ & 0 & 81 & 0 & 45 & 0 & 1 & 0 & 18 \\
\hline Sum & 0 & 181 & 0 & 177 & 0 & 176 & 0 & 145 \\
\hline
\end{tabular}

\subsection{Starch Content, Starch Yield and Storage Root Dry Weight}

At final harvest, the results indicated that the crops planted in the hot-dry (20-Apr), late-rainy (5-Oct) and cool seasons (15-Dec) had a higher starch contents than did the crops grown in the early-rainy season (30-Jun) (Figure 2A). There were significant differences between irrigated and rainfed crops for starch content for all planting dates. Over all of the planting dates, the rainfed crops had a higher starch content (85.0\%) than the irrigated crops (81.4\%) (Figure 2D). Planting dates were also significantly different for starch content.

There were no statistically significant differences between irrigated and rainfed crops for starch yield for most planting dates, except for the crop planted in the hot-dry season (20-Apr), in which the irrigated crop $\left(16,489 \mathrm{~kg} \mathrm{ha}^{-1}\right)$ was significantly higher than the rainfed crops $\left(9022 \mathrm{~kg} \mathrm{ha}^{-1}\right)$ (Table 3). The four planting dates produced significant differences in starch yield, ranging from 9227 to $14,489 \mathrm{~kg} \mathrm{ha}^{-1}$ for irrigated crops and 9022 to $17,779 \mathrm{~kg} \mathrm{ha}^{-1}$ for rainfed crops. Similarly, in irrigated crops, the planting date with the highest starch content also had the highest starch yield. The results clearly indicated the highest starch yield was recorded for the crop planted in the hot-dry (20-Apr), the late-rainy (5-Oct) and the cool seasons (15-Dec), with values of $14,849 \mathrm{~kg} \mathrm{ha}^{-1}, 14,974 \mathrm{~kg} \mathrm{ha}^{-1}$ and 
$15,929 \mathrm{~kg} \mathrm{ha}^{-1}$, respectively. Whereas the irrigated crops planted in the early-rainy season (30-Jun) had the lowest starch yield, with an average value of $9227 \mathrm{~kg} \mathrm{ha}^{-1}$ (Table 3).

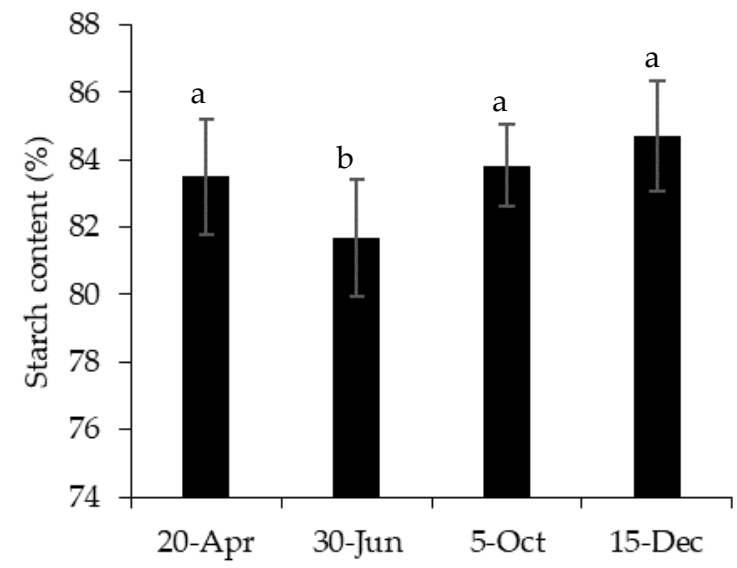

(A)
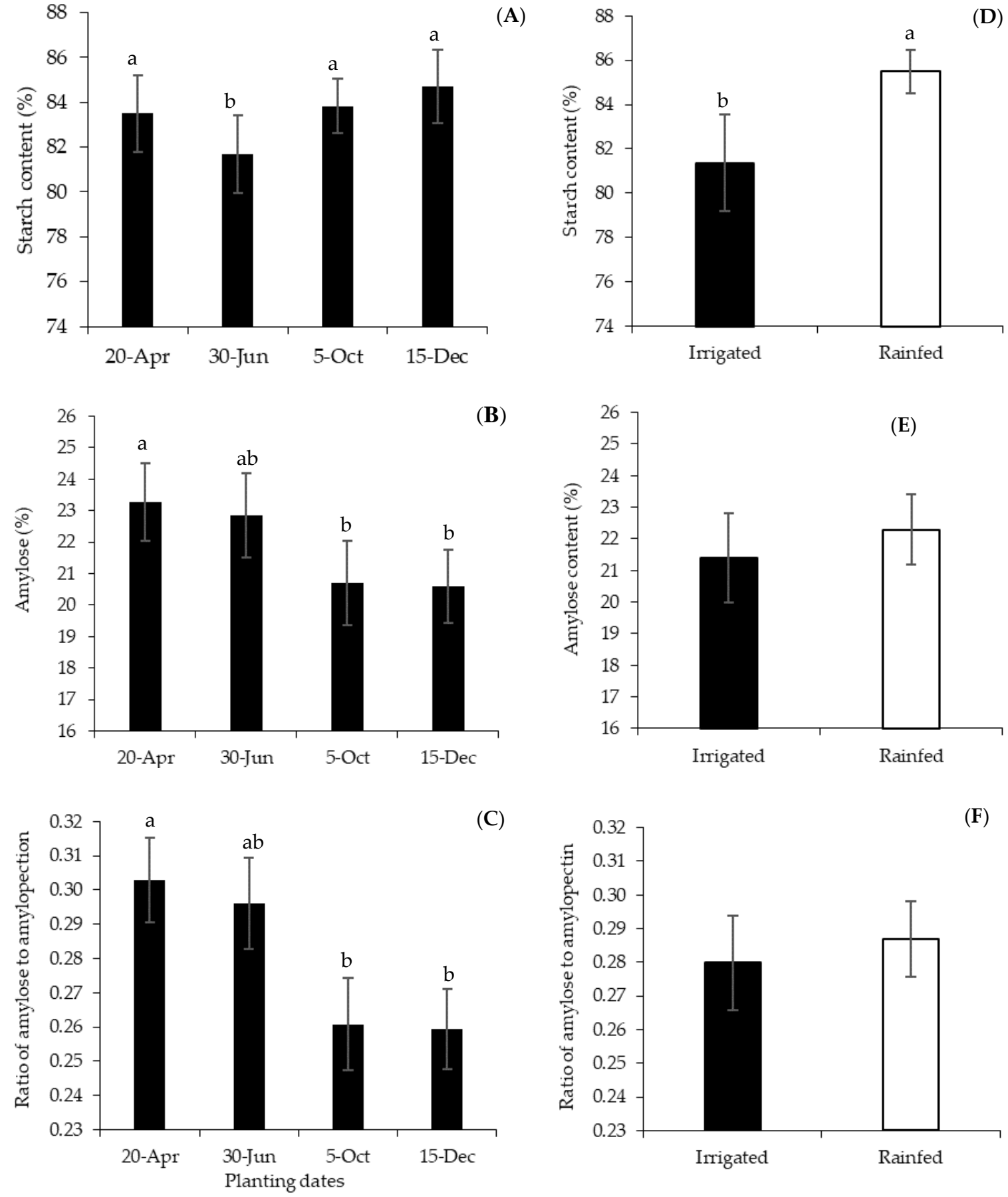

Figure 2. Means for starch content (\%) (A), amylose content (\%) (B) and ratio of amylose to amylopectin (C) of cassava cv. Rayong 9 for both irrigated and rainfed conditions at harvest (12 months after planting (MAP)) and comparison of means between irrigated and rainfed conditions for those traits (D-F). The different letters are significantly different by Duncan's multiple range test (DMRT) $(p<0.05)$. Mean between irrigation and rainfed treatments was tested statistically by least significant difference (LSD). The Vertical bar indicates standard deviation. 
Table 3. Means for starch yield $\left(\mathrm{kg} \mathrm{ha}^{-1}\right)$ and storage root dry weight $\left(\mathrm{kg} \mathrm{ha}^{-1}\right)$ of cassava cv. Rayong 9 under irrigated and rainfed conditions at harvest (12 months after planting (MAP)).

\begin{tabular}{|c|c|c|c|c|c|c|}
\hline \multirow{2}{*}{ Planting Date } & \multicolumn{2}{|c|}{$\begin{array}{l}\text { Starch Yield } \\
\left(\mathrm{kg} \mathrm{ha}^{-1}\right)\end{array}$} & \multirow{2}{*}{ LSD } & \multicolumn{2}{|c|}{$\begin{array}{l}\text { Storage Root Dry Weight } \\
\left(\mathrm{kg} \mathrm{ha}^{-1)}\right.\end{array}$} & \multirow{2}{*}{ LSD } \\
\hline & Irrigated & Rainfed & & Irrigated ${ }^{+}$ & Rainfed & \\
\hline 20-Apr & $14,489 a$ & $9022 c$ & $* *$ & $20,240 a$ & $10,538 c$ & $* *$ \\
\hline 30-Jun & $9227 b$ & $9339 c$ & ns & $11,601 b$ & $11,161 \mathrm{c}$ & ns \\
\hline 5-Oct & $14,974 \mathrm{a}$ & $15,004 b$ & ns & $18,437 \mathrm{a}$ & $17,350 \mathrm{~b}$ & ns \\
\hline 15-Dec & $15,929 a$ & $17,779 a$ & ns & $19,114 \mathrm{a}$ & $20,628 \mathrm{a}$ & ns \\
\hline Mean & 14,155 & 12,786 & & 17,348 & 14,919 & \\
\hline
\end{tabular}

Means in the same column with the same letters are not significantly different by Duncan's multiple range test (DMRT) $(p<0.05)$. ns and ${ }^{* *}=$ nonsignificant and significant at $p<0.01$, respectively, by least significant difference (LSD). ${ }^{+}$Storage root dry weight for irrigated crops was previously published by Phoncharoen et al. [10].

Results of the rainfed crops revealed that the crop planted in the cool season (15-Dec) had a higher starch yield $\left(17,779 \mathrm{~kg} \mathrm{ha}^{-1}\right)$ than did the crop planted in the late-rainy seasons (5-Oct) $\left(15,004 \mathrm{~kg} \mathrm{ha}^{-1}\right)$, whereas rainfed crops planted in the hot-dry (20-Apr) and early-rainy seasons (30-Jun) had the lowest starch yields, with average values of $9022 \mathrm{~kg} \mathrm{ha}^{-1}$ and $9339 \mathrm{~kg} \mathrm{ha}^{-1}$, respectively (Table 3).

Similarly, the planting date with the highest starch yield also had the highest storage root dry weight. The parallel study of the irrigated crops indicated that the highest storage root dry weight was observed for the crop planted in the hot-dry (20-Apr), the late-rainy (5-Oct) and the cool seasons (15-Dec), with the values of $20,240 \mathrm{~kg} \mathrm{ha}^{-1}, 18,437 \mathrm{~kg} \mathrm{ha}^{-1}$ and $19,114 \mathrm{~kg} \mathrm{ha}^{-1}$, respectively. Whereas the irrigated crops planted in the early-rainy season (30-Jun) had the lowest storage root dry weight, with an average value of $11,601 \mathrm{~kg} \mathrm{ha}^{-1}$ (Table 3).

For the rainfed crops, our results revealed that the crop planted in the cool season (15-Dec) had a higher storage root dry weight $\left(20,628 \mathrm{~kg} \mathrm{ha}^{-1}\right)$ than the crop planted in the late-rainy season (5-Oct) $\left(17,350 \mathrm{~kg} \mathrm{ha}^{-1}\right)$, whereas rainfed crops planted in the hot-dry (20-Apr) and early-rainy seasons (30-Jun) had the lowest storage root dry weights, with the average values of $10,538 \mathrm{~kg} \mathrm{ha}^{-1}$ and $11,161 \mathrm{~kg} \mathrm{ha}^{-1}$, respectively (Table 3 ).

\subsection{Starch Granule Size Distribution, Amylose and Ratio of Amylose to Amylopectin}

Significant difference between irrigated and rainfed crops for starch granules were not observed for all planting dates (Table 4$)$. The four planting dates had mean starch granules $(d 0.5)$ ranging from $15.94 \mu \mathrm{m}$ to $16.47 \mu \mathrm{m}$ for irrigated crops and $15.82 \mu \mathrm{m}$ to $17.33 \mu \mathrm{m}$ for rainfed crops. However, the rainfed crops seem to have bigger mean starch granules $(d 0.5)$ than the irrigated crops for the crops planted in the late-rainy (5-Oct) and cool seasons (15-Dec), as well as a higher percentage of small starch granules ( $d 0.1$ ). Additionally, there was no statistically significant differences among planting dates with respect to mean starch granules. However, the crops planted in the late-rainy (5-Oct) and cool seasons (15-Dec) tended to have bigger mean starch granules than the crops planted in the hot-dry (20-Apr) and early-rainy (30-Jun) seasons, especially for the rainfed crops (Table 4).

Likewise, significant differences between irrigated and rainfed crops for amylose content and ratio of amylose to amylopectin were not observed. Over all of the planting dates, the values of amylose for irrigated and rainfed crops were $21.40 \%$ and $22.29 \%$, respectively (Figure 2E). Whereas, the values of the ratio of amylose to amylopectin for irrigated and rainfed crops were 0.27 and 0.29 , respectively (Figure 2F). However, significant differences among planting dates were found for both amylose content and the ratio of amylose to amylopectin (Figure 2B,C), in which the crops planted in the hot-dry (20-Apr) and early-rainy seasons (30-Jun) had higher amylose contents and ratios of amylose to amylopectin than the crops planted in the late-rainy (5-Oct) and cool seasons (15-Dec). 
Table 4. Means for granule size distribution of starch isolated from storage roots of cassava cv. Rayong 9 under irrigated and rainfed condition at harvest (12 MAP).

\begin{tabular}{ccccccc}
\hline \multirow{2}{*}{ Planting Date } & \multicolumn{4}{c}{ Granule Size Distribution $(\boldsymbol{\mu m})$} \\
\cline { 2 - 7 } & \multicolumn{3}{c}{ Irrigated } & \multicolumn{3}{c}{ Rainfed } \\
\cline { 2 - 7 } & $\boldsymbol{d}$ & $\boldsymbol{d}$ & $\boldsymbol{d}$ & $\boldsymbol{d}$ & $\boldsymbol{d}$ & $\boldsymbol{d}$ \\
& $\mathbf{( 0 . 1 )}$ & $\mathbf{( 0 . 5 )}$ & $\mathbf{( 0 . 9 )}$ & $\mathbf{( 0 . 1 )}$ & $\mathbf{( 0 . 5 )}$ & $\mathbf{( 0 . 9 )}$ \\
\hline 20-Apr & 7.21 & 15.94 & $29.39 \mathrm{~b}$ & 6.71 & 15.82 & $30.04 \mathrm{~b}$ \\
30-Jun & 7.81 & 16.47 & $31.81 \mathrm{a}$ & 7.32 & 15.89 & $30.80 \mathrm{~b}$ \\
5-Oct & 7.82 & 16.24 & $31.16 \mathrm{a}$ & 7.96 & 17.33 & $33.78 \mathrm{a}$ \\
15-Dec & 7.31 & 16.16 & $30.96 \mathrm{a}$ & 8.54 & 17.19 & $31.34 \mathrm{ab}$ \\
\hline Mean & 7.54 & 16.2 & 30.83 & 7.63 & 16.56 & 31.49 \\
\hline
\end{tabular}

$d(0.1), d(0.5)$ and $d(0.9)$ are standard percentiles referred to as $10 \%, 50 \%$ and $90 \%$ of total starch that has a diameter $(\mathrm{mm})$ less than the indicated values, respectively. Means in the same column with the same letters are not significantly different at $p<0.05$ by DMRT. There were no statistically significant differences between water regimes in each granule group for all planting dates at $p<0.05$ by LSD.

\subsection{Combined Analysis of Variance}

Planting dates were significantly difference for all traits, i.e., starch content, starch yield, starch granule size, amylose content and ratio of amylose and amylopectin (Table 5). Water regimes were significant for starch content and starch yield but not for the starch granule size, amylose content and ratio of amylose and amylopectin. Planting date accounted for the largest variations for starch yield $(60.8 \%)$, starch granule size (38.2\%), amylose content (50.5\%) and the ratio of amylose to amylopectin $(53.7 \%)$, whereas the water regimes had the largest effects on starch content $(52.1 \%)$. The interaction between planting dates and water regimes were significant and accounted for a large portion of total variations for starch yield (24.7\%) and starch granule size (33.0\%).

Table 5. Mean squares from combined analysis of variance for starch content, starch yield, granule size $(d(0.05))$, amylose content and ratio of amylose to amylopectin of cassava cv. Rayong 9 at harvest stage using four planting dates.

\begin{tabular}{ccccccc}
\hline $\begin{array}{c}\text { Source of } \\
\text { Variance }\end{array}$ & df & $\begin{array}{c}\text { Starch } \\
\text { Content (\%) }\end{array}$ & $\begin{array}{c}\text { Starch Yield } \\
\mathbf{( k g ~ h a}^{-1} \mathbf{)}\end{array}$ & $\begin{array}{c}\text { Granule Size } \\
(\boldsymbol{d} \mathbf{( 0 . 0 5 ) )}\end{array}$ & $\begin{array}{c}\text { Amylose } \\
\mathbf{( \% )}\end{array}$ & $\begin{array}{c}\text { Ratio of Amylose } \\
\text { to Amylopectin }\end{array}$ \\
\hline Planting date (D) & 3 & $12.91(14.8)^{*}$ & $84,800,000(60.8)^{* *}$ & $0.721(38.2)^{*}$ & $15.66(50.5)^{* *}$ & $0.00461(53.7)^{* *}$ \\
Reps within D & 12 & $2.81(12.9)$ & $2,190,282(6.3)$ & $0.081(5.2)$ & $1.79(15.8)$ & $0.00050(16.3)$ \\
Water regime (W) & 1 & $136.13(52.1)^{* *}$ & $14,990,000(3.6)^{*}$ & $0.501(7.9)^{\mathrm{ns}}$ & $6.46(6.3)^{\mathrm{ns}}$ & $0.00151(5.3)^{\mathrm{ns}}$ \\
D $\times$ W & 2 & $1.88(2.2)^{\mathrm{ns}}$ & $34,460,000(24.7)^{* *}$ & $0.695(33.0)^{*}$ & $2.16(6.3)^{\mathrm{ns}}$ & $0.00055(5.8)^{\mathrm{ns}}$ \\
Pooled error & 12 & $3.94(18.1)$ & $1,639,082(4.7)$ & $0.310(15.6)$ & $1.82(21.1)$ & $0.00045(18.8)$ \\
\hline CV a (\%) & & 2.01 & 10.99 & 1.74 & 6.12 & 8.00 \\
CV b (\%) & & 2.38 & 9.50 & 3.40 & 6.17 & 7.52
\end{tabular}

Numbers within the parenthesis are percent of sum squares to total sum of squares. $\mathrm{ns},{ }^{*}$ and ${ }^{* *}=$ nonsignificant, significant at $p<0.05$ and significant at $p<0.01$ level, respectively. $\mathrm{df}=$ degree of freedom. $d(0.05)$ indicates the size of the particle expressed as a mass median diameter, at which $50 \%$ of the sample is smaller and $50 \%$ is larger than this size.

\subsection{Stepwise Analysis}

Stepwise regression analysis showed that the variation in the starch content for irrigated crops could be described by the solar radiation during 1-6 MAP with a determination coefficient $\left(R^{2}\right)$ of 0.38-0.45 (Table 6). Whereas, the variation in the starch content for irrigated crops during 6-9 MAP and 9-12 MAP was described by the solar radiation $\left(R^{2}=0.35\right)$ and the relative humidity $\left(R^{2}=0.44\right)$, respectively. For rainfed crops, the variation in the starch content could be described by the rainfall during 1-3 MAP $\left(R^{2}=0.48\right)$, whereas the variation in the starch content for rainfed crops during 3-6 MAP and 9-12 MAP could be described by the solar radiation $\left(\mathrm{R}^{2}=0.38\right)$. A combination of the solar radiation and the maximum air temperature during 6-9 MAP explained the variation in the starch content with an $\mathrm{R}^{2}$ value of 0.49 . 
Table 6. The stepwise regression analysis for the starch content (\%) and climatic factors of cassava cv. Rayong 9 for both irrigated and rainfed conditions.

\begin{tabular}{|c|c|c|c|c|}
\hline $\begin{array}{l}\text { Months after } \\
\text { Planting }\end{array}$ & Variable & Coefficient & $t$ & $\begin{array}{l}\text { Determination } \\
\text { Coefficient }\left(\mathbf{R}^{2}\right)\end{array}$ \\
\hline \multicolumn{5}{|c|}{ Starch content $(\%)$ for irrigated crops } \\
\hline \multirow[t]{2}{*}{$1-3$} & Constant & 81.31 & $8.82 *$ & \multirow{2}{*}{0.38} \\
\hline & Solar radiation & 2.85 & $2.88 *$ & \\
\hline \multirow[t]{2}{*}{$3-6$} & Constant & 80.62 & $19.8 *$ & \multirow{2}{*}{0.45} \\
\hline & Solar radiation & 1.82 & $2.8 *$ & \\
\hline \multirow[t]{2}{*}{$6-9$} & Constant & 53.41 & $4.98^{* *}$ & \multirow{2}{*}{0.35} \\
\hline & Photoperiod (h) & 3.10 & $4.15^{*}$ & \\
\hline \multirow[t]{2}{*}{$9-12$} & Constant & 68.55 & $18.1^{* *}$ & \multirow{2}{*}{0.44} \\
\hline & Relative humidity (\%) & 1.09 & $3.44 *$ & \\
\hline \multicolumn{5}{|c|}{ Starch content (\%) for rainfed crops } \\
\hline \multirow[t]{2}{*}{$1-3$} & Constant & 85.4 & $84.5 *$ & \multirow{2}{*}{0.42} \\
\hline & Rainfall & -1.38 & $-1.89 *$ & \\
\hline \multirow[t]{2}{*}{$3-6$} & Constant & 98.1 & $79.88 *$ & \multirow{2}{*}{0.38} \\
\hline & Solar radiation & 1.42 & $2.10 *$ & \\
\hline \multirow[t]{2}{*}{$6-9$} & Constant & 80.70 & $18.30 * *$ & \multirow{3}{*}{0.40} \\
\hline & Solar radiation & 0.01 & $4.17^{* *}$ & \\
\hline \multirow{3}{*}{$9-12$} & Maximum air temperature (\%) & -0.31 & $-2.85 *$ & \\
\hline & Constant & 101.1 & $23.27 * *$ & \multirow{2}{*}{0.38} \\
\hline & Solar radiation & -9.71 & $-3.61^{* *}$ & \\
\hline
\end{tabular}

The variation in starch yield could be described by a combination of total solar radiation, mean air temperature and rainfall during 1-3 MAP for irrigated crops $\left(R^{2}=0.82\right)($ Table 7$)$. Whereas, mean air temperature during 1-3 MAP explained the variation in the starch yield for rainfed crops with an $\mathrm{R}^{2}$ of 0.83 . During 3-6 MAP and 9-12 MAP, a combination of solar radiation, photoperiod and relative humidity described the variation in the starch yield for irrigated crops $\left(R^{2}=0.83-0.92\right)$. A combination of photoperiod, relative humidity and rainfall explained the variation in the starch yield for irrigated crops at 6-9 MAP with an $\mathrm{R}^{2}$ of 0.82 . The variation in starch yield for rainfed crops could be described by a combination relative air humidity and photoperiod during 3-12 MAP with an $R^{2}$ of 0.91-0.92. Furthermore, the stepwise regression analysis indicated that the variations in amylose content and starch granule size were not significantly related with all the climatic factors for the both irrigated and rainfed crops with low values of $R^{2}$.

The solar radiation would be the most important factors for starch content, as indicated by the maximum absolute $t$ value for both irrigated and rainfed crops. Irrigated crops during 6-9 and 9-12 MAP and rainfed crops during 1-3 MAP were the exception, as they showed the maximum absolute $t$ value for the photoperiod, relative humidity and rainfall, respectively (Table 6). Whereas, the solar radiation, mean air temperature and relative humidity would be the most important factors for starch yield at early to mid-growth stages for irrigated crops, as indicated by the maximum absolute $t$ value, but for rainfed crops, the mean air temperature and relative air humidity would be the most important factors effecting starch yield during these growth stages. During the mid to late-growth stages, the stepwise analysis indicated that the photoperiod and relative humidity showed the maximum absolute $t$ value at 6-12 MAP for both irrigated and rainfed crops (Table 7). 
Table 7. The stepwise regression analysis for the starch yield $\left(\mathrm{kg} \mathrm{ha}^{-1}\right)$ and climatic factors of cassava cv. Rayong 9 for both irrigated and rainfed conditions.

\begin{tabular}{|c|c|c|c|c|}
\hline $\begin{array}{l}\text { Months after } \\
\text { Planting }\end{array}$ & Variable & Coefficient & $t$ & $\begin{array}{l}\text { Determination } \\
\text { Coefficient }\left(\mathbf{R}^{2}\right)\end{array}$ \\
\hline \multicolumn{5}{|c|}{ Starch yield $\left(\mathrm{kg} \mathrm{ha}^{-1}\right)$ for irrigated crops } \\
\hline \multirow[t]{4}{*}{$1-3$} & Constant & -2.53 & $-6.26^{* *}$ & \multirow{4}{*}{0.82} \\
\hline & Solar radiation & $-74,033$ & $-5.25 * *$ & \\
\hline & Mean air temperature & 3.18 & $5.25^{* *}$ & \\
\hline & Rainfall & $-57,471$ & $-4.28 * *$ & \\
\hline \multirow[t]{4}{*}{$3-6$} & Constant & $-400,029$ & $-4.24 * *$ & \multirow{4}{*}{0.83} \\
\hline & Solar radiation & -36.61 & $-7.67^{* *}$ & \\
\hline & Photoperiod (h) & $10,073.7$ & $4.13 * *$ & \\
\hline & Relative humidity (\%) & -182.73 & $-3.97 * *$ & \\
\hline \multirow[t]{4}{*}{$6-9$} & Constant & $-125,540$ & $-5.10 * *$ & \multirow{4}{*}{0.82} \\
\hline & Photoperiod (h) & 8724 & $5.97 * *$ & \\
\hline & Relative humidity (\%) & 731.7 & $6.70 * *$ & \\
\hline & Rainfall & -39.7 & $-5.21 * *$ & \\
\hline \multirow[t]{4}{*}{$9-12$} & Constant & 44,122 & $3.64^{* *}$ & \multirow{4}{*}{0.84} \\
\hline & Solar radiation & -70.1 & $-3.29 * *$ & \\
\hline & Photoperiod (h) & 8223 & $4.55^{* *}$ & \\
\hline & Relative humidity (\%) & -254.5 & $-4.16^{* *}$ & \\
\hline \multicolumn{5}{|c|}{ Starch yield $\left(\mathrm{kg} \mathrm{ha}^{-1}\right)$ for rainfed crops } \\
\hline \multirow[t]{2}{*}{$1-3$} & Constant & 78,631 & 5.88 & \multirow{2}{*}{0.83} \\
\hline & Mean air temperature & -5364 & -4.93 & \\
\hline \multirow[t]{3}{*}{$3-6$} & Constant & $-12,547$ & $-1.78^{\mathrm{ns}}$ & \multirow{4}{*}{0.92} \\
\hline & Photoperiod (h) & 3624 & $6.18 * *$ & \\
\hline & Relative humidity (\%) & -285 & $-11.82 * *$ & \\
\hline \multirow[t]{3}{*}{$6-9$} & Constant & $-46,399$ & $-8.18^{* *}$ & \\
\hline & Photoperiod (h) & 4224 & $7.73^{* *}$ & \multirow[t]{2}{*}{0.91} \\
\hline & Relative humidity (\%) & 140 & $3.46^{* *}$ & \\
\hline \multirow[t]{3}{*}{$9-12$} & Constant & 41,178 & $5.09 * *$ & \multirow{3}{*}{0.91} \\
\hline & Photoperiod (h) & -3835 & $-5.70 * *$ & \\
\hline & Relative humidity (\%) & 280 & $11.19^{* *}$ & \\
\hline
\end{tabular}

$t=t$-test (or student) and ns and ${ }^{* *}=$ non significant and significant differences at $p<0.01$, respectively. Climatic factors were used to examine the relationship between the starch characteristics as follows: total solar radiation, minimum and maximum temperatures, mean temperature, growing degree-days, photoperiod, relative humidity, rainfall and water supplied.

\section{Discussion}

The evidence in terms of choosing the appropriate planting date for cultivation under irrigated and rainfed conditions is necessary for designing management guidelines with respect to water management and planting time in order to obtain optimum starch yield for both irrigated and rainfed conditions, with the irrigations are being used by the cassava farmers if water resources are available [21].

Significant differences among planting dates were observed for all traits (i.e., starch content, starch yield, starch granule size, amylose and ratio of amylose to amylopectin), but significant differences between water regimes were observed for starch content and starch yield only (Table 5). Planting date by water regime interactions were also significant for starch yield and mean starch granules. Planting dates accounted for the largest proportion of variation for most cassava traits $(38.2 \%-60.8 \%)$, except for starch content, which was greatly affected by water regimes $(52.1 \%)$. These results were similar to a previous investigation of cassava biomass and storage root yield reported by Mahakosee et al. [22]. They reported that planting date had a greater effect in comparison to water regimes and planting date by water regime interactions. Another study under well-watered conditions indicated that the planting date was a major factor affecting starch yield and starch granule size [8]; however, under rainfed conditions, starch content was strongly affected by water stress [12,23].

Rainfed crops planted in the hot-dry (20-Apr) and early-rainy seasons (30-Jun) received sufficient water to support early growth but faced water stress at mid to late-seasons growth stages (Table 2). Rainfed crops planted in the late-rainy (5-Oct) and cool seasons (15-Dec) did not receive sufficient water for early growth and had water stress in early to mid-season growth stages (Table 2). In this study, however, water stress at any growth stage was not detrimental to starch yield, starch granules, amylose and ratio of amylose to amylopectin for most planting seasons, except for starch content and starch yield of the crop planted in the hot-dry season (20-Apr) (Table 3). The rainfed crop planted 
in the hot dry-season (20-Apr) had a significantly higher starch content than did the irrigated crop (Figure 2D), but a higher starch yield was obtained for the irrigated crop (Table 3).

Cassava has the ability to recover from drought once water becomes available. Santisopasri et al. [12] planted six cassava genotypes at the start of the rainy season and after the rainy season without supplementary irrigation. The authors indicated that initial water stress for the first six months decreased cassava starch content and starch yield at 6 MAP by $78.0 \%$ to $81.4 \%$ and $97.2 \%$ to $99.1 \%$, respectively; thereafter, cassava had the ability to recover starch content and starch yield at $12 \mathrm{MAP}$ with only decreasing by $11.6 \%$ to $41.3 \%$ and $31.1 \%$ to $63.4 \%$, respectively. The six cassava genotypes tested responded differently to drought stress. Earlier reports stated that, once the crop is established, cassava can avoid or reduce drought stress for long periods of no rain by partial closure of stomata, deep rooting systems and small canopy size. Consequently, cassava can recover from drought stress when water becomes available in a second wet cycle by rapidly producing new leaves with high photosynthetic capabilities [24-26].

As in our study, Teerawanichpan et al. [13] and Defloor et al. [14] also stated that drought stress (under rainfed conditions) had a minor effect on amylose and amylopectin in the storage root of cassava. In contrast, cassava planted in the rainy season (without initial water-stressed crops) had larger starch granules than did the crop planted in the post-rainy season (with initial water-stressed crops) $[13,23]$. The difference of the results between our study and previous reports could be due to a variation in cassava genotype, water management or drought severity, as well as the timing and duration of drought events.

In the current study, significant differences for starch content and starch yield between irrigated and rainfed crops were recorded only for the crop in the 20-Apr planting. This may be due to severe drought stress at late-growth stages during Sep to Mar (as indicated by soil water potential below the critical level at 7 to 9 MAP and 10 to 12 MAP for 90 days and 81 days, respectively), consequently, leading to a significant decrease in the starch yield of rainfed crops. However, the soil moisture reserves seemed to be adequate for the rainfed crops planted in other planting dates. In other tuber crop, the evidence has shown that mid to late-season droughts had negative effects on sink growth and starch yield of potato tubers by promoting biosynthesis of sucrose instead of starch biosynthesis [27], as well as inhibiting carbohydrates' translocation to the sink [28]. However, this result is in contrast to the results of cassava reported by Santisopasri et al. [12] and Defloor et al. [14], indicating that late-season droughts had less detrimental effects than early-season droughts. According to our results, it is recommended that, only for the crop planted in the hot-dry season (20-Apr), irrigation at the late-growth stages during Sep to Mar might help to increase starch yield. In contrast, once cassava is established, irrigation is unnecessary for other planting dates, because residual soil moisture would be adequate for crop growth.

In this study, we noted that most cassava starch traits were affected by planting dates. The planting date with the highest starch yield in each water regime also had the highest storage root dry weight. This is mainly due to the fact that starch yield is related with storage root dry weight. Results for irrigated crops indicated that cassava planted in the hot-dry (20-Apr), late-rainy (5-Oct) and cool seasons (15-Dec) had higher starch contents, starch yields and storage root dry weights than did cassava planted in the early-rainy season (30-Jun) (Table 3 and Figure 1A). Higher starch yields and storage root dry weights were also recorded for rainfed crops planted in the late-rainy season (5-Oct) and cool season (15-Dec) (Table 3). These two planting dates also seemed to have bigger starch granule sizes in both irrigated and rainfed crops. As water regimes had minor effects on crop differences, the crop differences could be due to other climatic factors.

According to the stepwise regression analysis, the variations in starch contents for both irrigated and rainfed crops were related with the solar radiation throughout the growth periods. The climatic factors during 6-9 and 9-12 MAP for irrigated crops and during 1-3 MAP for rainfed crops were the exceptions, as they were related with the photoperiod, relative humidity and rainfall, respectively (Table 6). Although starch content was related with rainfall during 1-3 months for rainfed crops, it does 
not appear to have much importance in climatic factors for starch content. This is due to low $\mathrm{R}^{2}$ for the rainfall (0.42). Moreover, low $\mathrm{R}^{2}$ were also recorded for all climatic factors that related with the starch content for both irrigated and rainfed crops $\left(R^{2}=0.38-0.44\right)$. However, highly significant relationships were recorded for starch yield. The solar radiation, mean air temperature and relative air humidity at early to mid-growth stages explained the variations in starch yield for irrigated crops $\left(R^{2}=0.82-0.83\right)$. Whereas, the mean air temperature and relative air humidity explained the variations in starch yield at mid to late-growth stages for rainfed crops $\left(R^{2}=0.83-0.92\right)$. In this study, the photoperiod and relative humidity explained the variations in starch yield at mid to late-growth stages for both irrigated and rainfed crops $\left(\mathrm{R}^{2}=0.82-0.91\right)$ (Table 7).

These findings were similar to a previous study on other cassava genotypes. Our previous reports under full-watered conditions have also demonstrated the effects of other climatic factors on starch yield and starch qualities where water is not the limiting factor, demonstrating that planting cassava in the post-rainy seasons (5-Oct and 15-Dec) had higher starch contents, starch yields and starch granules than did the crops planted in the early rainy seasons (20-Apr and 30-Jun) [8]. The authors also explained that crops planted in the post-rainy seasons experienced optimal conditions during the stages of canopy growth and storage root bulking for crop growth (high temperature, high solar radiation and high ambient relative humidity), resulting in higher accumulation of starch in storage roots. Thereafter, the crops planted in these two planting dates also experienced lower temperature and shorter photoperiod at late-growth stages, resulting in a higher partitioning of assimilates (starch) from shoots to the storage roots. Similar responses in growth and storage root yield to climatic factors have been reported by Phonjaroen et al. [10], Keating et al. [29] and Fukai et al. [30].

Studies by El-Sharkawy et al. [31] and Saithong et al. [32] indicated that a temperature range between 25 to $35^{\circ} \mathrm{C}$ during early to mid-growth stages is optimum for cassava crop growth and results in increased activities of the enzymes involved in photosynthesis and the synthesis of starch. High temperatures and high solar radiation during the early to mid-growth stages also increased canopy size, leaf growth rate and leaf area index $[22,33,34]$.

For the other two planting dates (20-Apr and 30-Jun), the crops were exposed to lower temperatures, lower solar radiation and lower ambient relative humidity during late-October to mid-May (cool season to hot season). This occurred during the period of canopy growth and storage root bulking. Consequently, it resulted in reduced photosynthesis capacity and crop growth [35-37]. Likewise, Vongcharoen et al. [38] indicated that the lowest leaf photosynthesis of cassava was recorded during the cool season when compared to the rainy and hot seasons, when solar radiation is a limiting factor. Temperatures below $17^{\circ} \mathrm{C}$ or above $30^{\circ} \mathrm{C}$ inhibited leaf growth and starch yield of cassava, and low relative ambient humidity caused partial stomatal closure, resulting in reduced crop growth $[26,37]$. Moreover, high temperatures and long photoperiods during the late-growth stage for these two planting dates resulted in a high shoot growth rate but a low distribution ratio of carbohydrates [39,40].

In this study, the highest amylose content and ratio of amylose to amylopectin were recorded for the crops planted in the hot and early-rainy seasons. In contrast, Janket et al. [8] observed that, under irrigated conditions, planting dates did not cause differences in the amylose content and ratio of amylose to amylopectin in cassava, but genotypes did. However, the differences might be due to differences in tested genotypes.

The lowest content and yield of starch were recorded in the early-rainy season (30-Jun) for both irrigated and rainfed crops (Table 3). Although the crops planted in the early-rainy season (30-Jun) experienced climatic factors during mid-growth stages similar to the hot-dry season (20-Apr), lower solar radiation with more clouds and heavy rainfalls $(547.2 \mathrm{~mm}$ ) and higher soil erosions during initial growth (after planting to $3 \mathrm{MAP}$ ) might have resulted in reduced (delayed) seedling establishment and development of the crops planted in the early-rainy season (30-Jun). Crops planted in this planting date also experienced high rainfall $(259.4 \mathrm{~mm})$, high solar radiation and high temperature at 11 to $12 \mathrm{MAP}$, resulting in the regrowth of cassava shoots (data not shown). Regrowth of cassava shoots has been correlated to a reduction in storage root yield and starch content [29]. A parallel study also 
indicated that low biomass production and storage roots' dry weights in cassava genotypes were recorded for the crops planted in the early-rainy season (30-Jun) [10]. This is due to the fact that the crops planted in this planting date had lower biomass accumulation rates and shorter periods in linear phases for the total biomass and storage root dry weights compared to other planting dates.

\section{Conclusions}

Starch yield, starch granule size, amylose content and ratio of amylose and amylopectin were mainly dependent on planting dates, whereas starch content was largely affected by water regimes. There were no significant differences between irrigated and rainfed crops for starch yield and other parameters for most planting dates, except for starch yield for the crops planted in the hot-dry season (20-Apr). Planting cassava in the late-rainy (5-Oct) and cool seasons (15-Dec) resulted in a greater starch content and starch yield at the final harvest than other planting dates for both irrigated and rainfed conditions. Irrigated crops had significantly higher starch yields than rainfed crops only for the crops planted in the hot-dry season (20-Apr). This pointed out that irrigation by a mini-sprinkler at 5-11 MAP during Sep to Mar for the Rayong 9 planted in the hot-dry season can help increase starch yield, whereas irrigation is unnecessary for other planting dates once this cassava cultivar is established. Rayong 9 planted in the early-rainy season (30-June) had the lowest starch content and starch yield for both irrigated and rainfed crops. The information obtained in this study is useful to understand starch yield and starch characteristic differences under irrigated and rainfed conditions at different planting dates and for designing cultural practices with respect to water application and planting periods in order to obtain the optimum starch yield and qualities under the tropical savanna climate in Northeast Thailand.

Author Contributions: Conceptualization, N.V., P.B., P.T. and S.J.; data curation, A.J.; formal analysis, A.J. and S.J.; investigation, A.J.; methodology, A.J., N.V., P.B. and S.J.; supervision, S.J.; writing-original draft, A.J. and writing-review and editing, B.T., W.K., P.B., C.C.H., C.C.K. and S.J. All authors have read and agreed to the published version of the manuscript.

Funding: This work was kindly supported by the Royal Golden Jubilee Ph.D. Program (grant no. PHD/0216/2560) and the National Science and Technology Development Agency (NSTDA), Thailand and the Peanut, Jerusalem artichoke and Cassava Improvement Research Group, Khon Kaen University.

Acknowledgments: Special thanks to the Khon Kaen University for providing facilities in conducing this experiment, and we would like to thank the members of the cassava team project and the technicians of the Agronomy Department for their help in field data collection and laboratory analyses.

Conflicts of Interest: The authors declare no conflict of interest.

\section{References}

1. El-Sharkawy, M.A. Cassava biology and physiology. Plant Mol. Biol. 2004, 56, 481-501. [CrossRef]

2. Howeler, R.; Lutaladio, N.; Thomas, G. Save and Grow: Cassava-A Guide to Sustainable Production Intensification; Food and Agriculture Organization: Rome, Italy, 2013.

3. Howeler, R.H. Sustainable Soil and Crop Management of Cassava in Asia: A Reference Manual; CIAT Publication: Hanoi, Vietnam, 2014.

4. Office of Agricultural Economics. Available online: http://www.oae.go.th (accessed on 13 April 2018).

5. Connor, D.J.; Cock, J.H. Response of cassava to water shortage. II. Canopy dynamics. Field Crops Res. 1981, 4, 285-296. [CrossRef]

6. El-Sharkawy, M.A. Drought-tolerant cassava for Africa, Asia, and Latin America. BioScience 1993, 43, 441-451. [CrossRef]

7. Alves, A.A.C. Cassava Botany and Physiology. In Cassava: Biology, Production and Utilization; Hillocks, R.J., Thresh, J.M., Bellotti, A., Eds.; CABI Publishing: New York, NY, USA, 2002; pp. 115-147. [CrossRef]

8. Janket, A.; Vorasoot, N.; Kesmala, T.; Jogloy, S. Influence of zinc, copper and manganese on dry matter yield and physiological traits of three cassava genotypes grown on soil micronutrient deficiencies. Pak. J. Bot. 2018, 50, 1719-1725. 
9. Sawatraksa, N.; Banterng, P.; Jogloy, S.; Vorasoot, N.; Hoogenboom, G. Chlorophyll fluorescence and biomass of four cassava genotypes grown under rain-fed upper paddy field condition in tropics. J. Agro. Crop Sci. 2018, 204, 554-565. [CrossRef]

10. Phoncharoen, P.; Banterng, P.; Vorasoot, N.; Jogloy, S.; Theerakulpisut, P.; Hoogenboom, G. Growth rates and yields of cassava at different planting dates in a tropical savanna climate. Sci. Agric. 2018, 76, 376-388. [CrossRef]

11. Reddy, B.V.S.; Ramesh, S.; Reddy, P.S. Sorghum breeding research at ICRISAT-goals, strategies, methods and accomplishments. Int. Sorghum Millets Newsl. 2004, 45, 5-12.

12. Santisopasri, V.; Kurotjanawong, K.; Chotineeranat, S.; Piyachomkwan, K.; Sriroth, K. Impact of water stress on yield and quality of cassava starch. Ind. Crops Prod. 2001, 13, 115-129. [CrossRef]

13. Teerawanichpan, P.; Lertpanyasampatha, M.; Netrphan, S.; Varavinit, S.; Boonseng, O.; Narangajavana, J. Influence of cassava storage root development and environmental conditions on starch granule size distribution. Starch Stärke 2008, 60, 696-705. [CrossRef]

14. Defloor, I.; Dehing, I.; Delcour, J.A. Physico-chemical properties of cassava starch. Starch Stärke 1998, 50, 58-64. [CrossRef]

15. Prammanee, S.; Kamprerasart, K.; Salakan, S.; Sriroth, K. Growth and starch content evaluation on newly released cassava cultivars, Rayong 9, Rayong 7 and Rayong 80 at different harvest times. Kasetsart J. 2010, 44, 558-563.

16. Good Agricultural Practices for Cassava. Available online: http://www.acfs.go.th/standard/download/eng/ GAP_cassava.pdf (accessed on 12 August 2018).

17. Howeler, R.H. Cassava Mineral Nutrition and Fertilization. In Cassava: Biology, Production and Utilization; Hillocks, R.J., Thresh, J.M., Bellotti, A., Eds.; CABI Publishing: New York, NY, USA, 2002; pp. 281-300.

18. Hoover, R.; Ratnayake, W.S. Current Protocols in Food Analytical Chemistry; John Wiley \& Sons: New York, NY, USA, 2001.

19. Gomez, K.A.; Gomez, A.A. Statistical Procedures for Agricultural Research, 2nd ed.; John Wiley and Sons: New York, NY, USA, 1984.

20. Freed, R.D.; Nissen, O. MSTAT-C Version 1.42; Michigan State University: East Lansing, MI, USA, 1992.

21. Polthanee, A.; Srisutham, M. Supplementary irrigation for cassava planted in the late rainy season of Northeastern Thailand. Asian J. Crop Sci. 2017, 9, 100-108. [CrossRef]

22. Mahakosee, S.; Jogloy, S.; Vorasoot, N.; Theerakulpisut, P.; Banterng, P.; Kesmala, T.; Holbrook, C.; Kvien, C. Seasonal variations in canopy size and yield of rayong 9 cassava genotype under rainfed and irrigated conditions. Agronomy 2019, 9, 362. [CrossRef]

23. Sriroth, K.; Piyachomkwan, K.; Santisopasri, V.; Oates, C.G. Environmental conditions during root development: Drought constraint on cassava starch quality. Euphytica 2001, 120, 95-101. [CrossRef]

24. Lahai, M.T.; Ekanayake, I.J.; Koroma, J.P.C. Influence of canopy structure on yield of cassava cultivars at various toposequences of an inland valley agro ecosystem. J. Agric. Biotech. Sustain. Dev. 2013, 5, 36-47. [CrossRef]

25. El-Sharkawy, M.A.; Cock, J.H. Response of cassava to water stress. Plant Soil 1987, 100, 345-360. [CrossRef]

26. El-Sharkawy, M.A.; De Tafur, S.M. Genotypic and within canopy variation in leaf carbon isotope discrimination and its relation to short-term leaf gas exchange characteristics in cassava grown under rain-fed conditions in the tropics. Photosynthetica 2007, 45, 515-526. [CrossRef]

27. Geigenberger, P.; Reimholz, R.; Geiger, M.; Merlo, L.; Canale, V.; Stitt, M. Regulation of sucrose and starch metabolism in potato tubers in response to short-term water deficit. Planta 1997, 201, 502-518. [CrossRef]

28. Cuellar-Ortiz, S.M.; De La Paz Arrieta Montiel, M.; Acosta-Gallegos, J.; Covarrubias, A.A. Relationship between carbohydrate partitioning and drought resistance in common bean. Plant Cell Environ. 2008, 31, 1399-1409. [CrossRef]

29. Keating, B.A.; Evenson, J.P.; Fukai, S. Environment effects on growth and development of cassava (Manihot esculenta Crantz) III. Assimilate distribution and storage organ yield. Field Crops Res. 1982, 5, 293-303. [CrossRef]

30. Fukai, S.; Alcoy, A.B.; Llamelo, A.B.; Patterson, R.D. Effects of solar radiation on growth of cassava (Manihot esculenta Crantz.). I. Canopy development and dry matter growth. Field Crops Res. 1984, 9, 347-360. [CrossRef] 
31. El-Sharkawy, M.A.; Cock, J.H.; Held, A.A. Photosynthetic responses of cassava cultivars (Manihot esculenta Crantz) from different habitats to temperature. Photosynth. Res. 1984, 5, 243-250. [CrossRef] [PubMed]

32. Saithong, T.; Rongsirikul, O.; Kalapanulak, S.; Chiewchankaset, P.; Siriwat, W.; Netrphan, S.; Suksangpanomrung, M.; Meechai, A.; Cheevadhanarak, S. Starch biosynthesis in cassava: A genome-based pathway reconstruction and its exploitation in data integration. BMC Syst. Boil. 2013, 7, 75. [CrossRef] [PubMed]

33. Irikura, V.; Cock, J.H.; Kawano, K. The physiological basis of genotype-temperature interactions in cassava. Field Crops Res. 1979, 2, 227-239. [CrossRef]

34. Okoli, P.S.; Wilson, G.F. Response of cassava (Manihot esculenta Crantz) to shade under field conditions. Field Crops Res. 1986, 14, 349-359. [CrossRef]

35. Aresta, R.B.; Fukai, S. Effects of solar radiation on growth of cassava Manihot esculenta Crantz II. Fibrous root length. Field Crop. Res. 1984, 9, 361-371. [CrossRef]

36. El-Sharkawy, M.A. Effect of humidity and wind on leaf conductance of field grown cassava. Rev. Bras. Fisiol. Vegetal. 1990, 2, 17-22.

37. El-Sharkawy, M.A. Stress tolerant cassava: The role of integrative ecophysiology breeding research in crop improvement. OJSS 2012, 162-186. [CrossRef]

38. Vongcharoen, K.; Santanoo, S.; Banterng, P.; Jogloy, S.; Vorasoot, N.; Theerakulpisut, P. Seasonal variation in photosynthesis performance of cassava at two different growth stages under irrigated and rain-fed conditions in a tropical savanna climate. Photosynthetica 2018, 56, 1398-1413. [CrossRef]

39. Boerboom, B.W. A model of dry matter distribution in cassava (Manihot esculenta Crantz). Neth. J. Agri. Sci. 1978, 26, 267-277.

40. Keating, B.A.; Evenson, J.P.; Fukai, S. Environmental effects on growth and development of cassava (Manihot esculenta Crantz) II. Crop growth rate and biomass yield. Field Crops Res. 1982, 5, 283-292. [CrossRef]

(C) 2020 by the authors. Licensee MDPI, Basel, Switzerland. This article is an open access article distributed under the terms and conditions of the Creative Commons Attribution (CC BY) license (http://creativecommons.org/licenses/by/4.0/). 